\title{
PENGEMBANGAN DAN VALIDASI METODE HIGH PERFORMANCE CHROMATOGRAPHY (HPLC) UNTUK ANALISIS SODIUM SEFTRIAKSON
}

\author{
Validation of High Performance Chromatography (HPLC) Method for Analysis of \\ Sodium Ceftriaxone
}

\author{
Alfan Danny Arbianto, Maya Damayanti Rahayu, Susi Kusumaningrum, Rohimmahtunnisa \\ Azhar, Raodatul Jannah \\ Pusat Teknologi Farmasi dan Medika, Badan Pengkajian dan Penerapan Teknologi, Tangerang Selatan \\ Indonesia \\ e-mail: alfan.danny@bppt.go.id
}

\begin{abstract}
Abstrak
Seftriakson merupakan antibiotik generasi ketiga dari kelas sefalosporin yang digunakan sebagai antibiotik penyakit infeksi pneumonia dan saluran kemih. Isu green chemistry dan pemenuhan syarat dari suatu regulasi pemasaran seperti USP (United State Pharmacopeia) atau EP (Europe Pharmacopeia) mengakibatkan membengkaknya biaya analisis sehingga setiap industry farmasi berlomba-lomba di dalam mengembangkan suatu metode analisis yang murah dan ramah lingkungan. Penelitian ini bertujuan untuk menvalidasi metode yang digunakan untuk analisis bahan baku seftriakson dengan menggunakan HPLC. Parameter yang digunakan untuk validasi metode pada penelitian ini meliputi keseuaian sistem, selektifitas, linieritas, akurasi, presisi, robustness, batas deteksi dan batas kuantifikasi. Analisis dilakukan menggunakan kolom inertsil ODS - 3, C-18, $(5 \mathrm{~mm}, 4.6 \times 150 \mathrm{~mm})$, fase gerak terdiri dari metanol-air 0,1\% TFA (35:65 v/v) dengan laju 1,0 mL/menit. Temperatur kolom dikondisikan pada suhu $25^{\circ} \mathrm{C}$ dan analisis dilakukan menggunakan detektor PDA(photodiode array) pada $235 \mathrm{~nm}$. Dari hasil analisis uji linieritas dihasilkan respon linieritas yang baik yaitu nilai koefisisen korelasi $\left(R^{2)}\right.$ : 1 Nilai recovery diperoleh sebesar 99-102\%, sedangkan untuk uji presisi $R S D<2 \%$. Pada penelitian ini dianalisis juga batas deteksi dan batas kuantifikasi berturut-turut sebesar $1.41 \mu \mathrm{g} / \mathrm{mL}$. dan di 4.69 $\mu \mathrm{g} / \mathrm{mL}$.
\end{abstract}

Kata kunci: seftriakson, validasi, HPLC.

\section{Abstract}

Ceftriaxone is a third generation antibiotic from the class of cephalosporin, which is acted as antibiotic specifically for pneumonia and urinary tract infections. This study aim was to validate the HPLC method for analysing raw ceftriaxone. System suitability, selectivity, linearity, accuracy, precision, $L O D$ and $L O Q$ were applied as the analysis parameters. Analysis was carried out using Inertsil ODS column - 3, C-18, (5mm, $4.6 \times 150 \mathrm{~mm}$ ) withmobile phase comprising methanol and 0.1\% water TFA in a ratio of 35:65 ( $/ \mathrm{v}$ ) at a flow rate of $1.0 \mathrm{~mL} /$ minute. The column temperature was conditioned at $250 \mathrm{C}$ and the analysis was performed using a PDA detector (photodiode array) at $235 \mathrm{~nm}$. This study showed excellent linear response with correlation coeffient (R2) values of with $R S D 0,31 \%$. In addition this method revealed that the limit of detection was at $1.41 \mu \mathrm{g} / \mathrm{mL}$ and limit of quantification was achieved at $4.69 \mu \mathrm{g} / \mathrm{mL}$

Kata kunci: ceftriaxone, validation, HPLC

\section{PENDAHULUAN}

Pengembangan suatu metode analisis merupakan metode pendahuluan yang harus dipersiapkan pada suatu pengembangan formulasi obat uji (obat copy) (Dolan \& Snyder, 2017). Proses pengembangan metode biasanya diawali dengan proses uji coba untuk mengindentifikasi kualitas peak dari suatu analit. Analit yang sering digunakan pertama kali dalam pengujian tersebut adalah bahan baku obat (bulk drug material) dari suatu sediaan yang nantinya akan digunakan oleh peneliti didalam membuat suatu sediaan formulasi. Beberapa metode yang direkomendasikan di kopendial dapat dilihat pada Tabel 1.

Proporsi tertinggi dari semua metode analisis kadar suatu bahan baku obat yang terlihat pada Tabel 1 menunjukan bahwa ada $44 \%$ metode HPLC yang dipublikasikan oleh USP dan $69,5 \%$ metode titrasi yang dipublikasi pada EP 4.0. Kedua metode tersebut terbukti selektif dan valid untuk mengukur kadar bahan baku obat. Oleh sebab itu biasanya metode-metode tersebut digunakan sebagai acuan pertama di dalam membuat metode analisis yang valid untuk mengukur kadar dari suatu produk formulasi 
(finish product). Penggunaan eksipien pada produk formulasi biasanya akan mengganggu selektifitas dari suatu metode, sehingga pengembangan metode analisis suatu produk formulasi lebih sering menggunakan instrument HPLC.HPLC merupakan suatu alat analisis yang didasarkan pada kemampuan fasa diam didalam memisahkan analit (obat) dengan eksipien, sehingga faktor kesalahan data karena adanya interferensi dari eksipen dapat diturunkan intensitasnya. Proses pemisahan tersebut biasanya membutuhkan waktu optimasi yang lama sehingga peneliti menghasilkan peak analit dengan purity peak $100 \%$. Oleh sebab itu, strategi pemilihan metode pada saat awal pengembangan sangatlah penting untuk menghasilkan metode yang valid didalam menganalisis produk formulasi.

Tabel 1. Proporsi metode pengujian kadar bahan baku obat (bulk drug material) pada

Europe Pharmacopeia 4,0 dan United State Pharmacopeia 27.

\begin{tabular}{|l|l|c|}
\hline \multicolumn{1}{|c|}{ Metode } & $\begin{array}{l}\text { Europe } \\
\text { Pharmacopeia } \\
\text { (\%) }\end{array}$ & $\begin{array}{l}\text { United } \\
\text { State } \\
\text { Pharmaco } \\
\text { peia (\%) }\end{array}$ \\
\hline HPLC & 15,5 & 44 \\
\hline GC & 2 & 2,5 \\
\hline Titrasi & 69,5 & 40,5 \\
\hline Asam-basa & 57,5 & 29,5 \\
\hline Aqueous mixtures & 21 & 5,5 \\
\hline Indikator & 6,4 & 4,5 \\
\hline Potensiometri & 14,5 & 1 \\
\hline Non-aqueous & 36,5 & 24 \\
\hline Indikator & 9,5 & 14 \\
\hline Potensiometri & 27 & 10 \\
\hline $\begin{array}{l}\text { Redoks lodometri, } \\
\text { Nitritometri, } \\
\text { lainnya) }\end{array}$ & 6,5 & 5,5 \\
\hline $\begin{array}{l}\text { kompleksiometri, } \\
\text { argentometri, } \\
\text { dan lainnya }\end{array}$ & 5,5 & 5,5 \\
\hline $\begin{array}{l}\text { Spektrofotometer UV- } \\
\text { Vis }\end{array}$ & 9,5 & 8,5 \\
\hline $\begin{array}{l}\text { Uji mkikrobiologi } \\
\text { (antibiotik) }\end{array}$ & 3 & 2,5 \\
\hline $\begin{array}{l}\text { IR, NMR, polarimetri, } \\
\text { fluorimetri, atomic } \\
\text { absorption } \\
\text { spectroscopy (AAS), } \\
\text { polarografi, } \\
\text { gravimetri, dan } \\
\text { lainnya) }\end{array}$ & 0,5 & 2 \\
\hline \multicolumn{1}{|c|}{ (Gorong, } \\
\end{tabular}

$$
\text { (Görög, 2005) }
$$

Senyawa yang digunakan dalam penelitian ini yaitu sodium seftriakson. Seftriakson merupakan salah satu jenis obat antibiotik injeksi yang diperoleh dari derivat sefalosporin generasi ketiga, mempunyai efek anti bakteri gram positif dan gram negatif.

Analisis seftriakson telah banyak dilakukan oleh beberapa peneliti yaitu HPLC (da Trindade \& Salgado, 2018; Hiremath \&
Mruthyunjayaswamy, 2009; J. Shah, Jan, \& Shah, 2013; R. Shah \& Jat, 2015; Tariq et al., 2010) spektrometri UV (Ethiraj, Thiruvengadam, Sampath, Vahid, \& Raj, 2014) dan infra red (Tariq et al., 2010). Metode HPLC merupakan metode yang paling banyak digunakan untuk analisis natrium seftriakson karena lebih cepat, akurat dan presisi(da Trindade \& Salgado, 2018). Sesuai dengan USP 42, analisis seftriakson menggunakan HPLC dengan fasa gerak tetradesilamonium bromida, tetraheptilamonium bromida, monobasic postasium fosfat, dibasic natrium fosfat, dodekahidrat, asam sitrat, dan natrium hidroksida dan asetonitril. Olehkarena itu pada penelitian ini dilakukan perubahan sistem analisis yang digunakan yaitu menggunakan fase gerak yang lebih ekonomis dan sederhana yaitu metanol dan air (TFA 0,1\%) dan dilakukan proses validasi. Parameter yang digunakan untuk validasi metode meliputi linieritas, presisi, akurasi, spesifisitas/selektivitas, kesesuaian sistem, limit deteksi dan limit kuantifikasi yang mengacu pada pedoman International Conference on Harmonisation (ICH) dan AOAC International.

Metode HPLC yang sudah tervalidasi membantu analis untuk menghasilkan data yang konsisten dan akurat, dimana metode tersebut memainkan peranan yang sangat penting dalam industri farmasi, mulai dari penemuan obat baru, sintesis bahan baku, formulasi, dan quality control(Paithankar, 2013).

Pada penelitian ini akan dilakukan suatu pengembangan metode HPLC produk formulasi yang berasal dari metode analisis bahan baku obat (bulk drug material). Kelayakan penggunaan metode analisis tersebut didasarkan pada hasil validasi dan analisis statistik dari suatu produk formulasi yang sudah dipasarkan

\section{TINJAUAN PUSTAKA}

Natrium seftriakson, Disodium $(6 R, 7 R) 7-[[(2 Z)-$ (2-aminothiazol-4 $y l$ (methoxyimino)acetyl] amino]-3-[[(2-methyl-6-oxido-5-oxo-2,5-

dihydro-1,2,4 triazin-3-yl)sulfanyl]methyl]-8oxo-5-thia-1 azabicyclo[4.2.0]oct- 2-ene-2carboxylate 3,5 hydratedengan rumus molekul C18H16N8Na2O7S3, 31/2H2O, (BM : 661.60 $\mathrm{g} / \mathrm{mol}$ ) dan untuk bentuk anhydrous C18H18N8O7S3 $(598.56 \mathrm{~g} / \mathrm{mol})$. (da Trindade \& Salgado, 2018). Sodium seftriakson berbentuk bubuk kristal berwarna putih sampai kuning pucat yang larut dalam air, sedikit larut dalam metanol dan etanol. Nilai $\mathrm{pH}$ untuk 
larutan $1 \%$ adalah 6,7. Warna larutan sodium seftriakson dari kuning pucat sampai kuning sawo, tergantung dari lamanya penyimpanan, konsentrasi dan diluen yang digunakan. Antibiotik ini merupakan generasi ketiga dari sefalosporin yang digunakan untuk penyakit infeksi pneumonia dan infeksi saluran kemih (da Trindade \& Salgado, 2018)

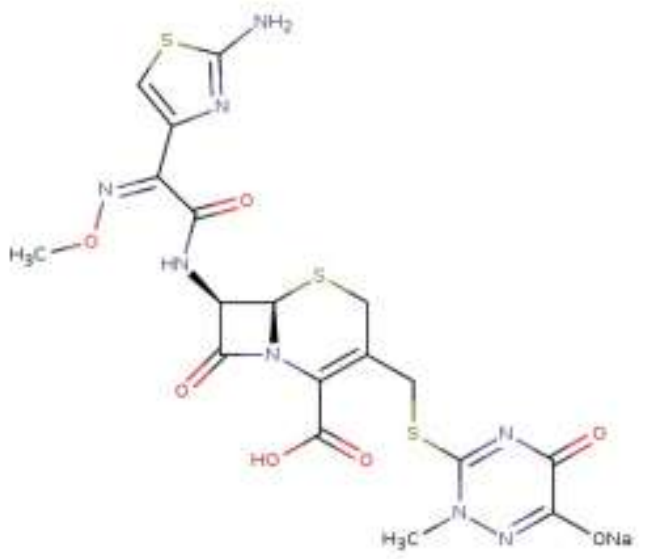

Gambar 1. Struktur Kimia Seftriakson

Sintesis natrium seftriakson diperoleh dari reaksi antara 7-amino-3-\{[(2,5-dihydro-6hydroxy-2-methyl-5-oxo-1 ,2,4-triazin-3yl)thio]methyl\}-3-cephem-4-carboxylic acid(7ACT) dan 2-mercaptobenzothiazoly(Z)-(2aminothiazole-4-yl)-2-methoxyimino acetate (MAEM) mengggunakan trietilamin sebagai katalis dan natrium asetat untuk membentuk garamnya (Danklmaier, Macher, \& Prager, 1996)

Parameter-parameter yang diperlukan untuk validasi metode HPLC meliputi: (a) Kesesuaian sistem, uji yang didasarkan pada konsep dimana peralatan, kondisi operasi analitik dan sampel merupakan bagian intergral dari sistem. uji pada HPLC meliputi resolusi, repeatability (RSD) untuk 5 kali ulangan, faktor tailing (b) Spesifisitas/selektifitas, kemampuan metode untuk membedakan antara analit dan komponen lain yang hadir pada sampel. Uji ini digunakan untuk mengevaluasi derajat interferensi yang disebabkan oleh analit lain, impuritas, degradasi produk, larutan blanko dan eksipien. (c) Linieritas, kemampuan untuk memperoleh hasil uji yang proporsional untuk konsentrasi sampel dalam rentang tertentu dimana pada HPLC linieritas menggambarkan hubungan antara konsentrasi sampel dan respon detektor (luas atau tinggi peak). (d) Akurasi, menggambarkan kedekatan antara nilai kebenaran yang diterima atau nilai referensi dengan nilai yang diperoleh, (e) Presisi, mengukur kemampuan sebuah metode menghasilkan data yang reproducible, (f) batas deteksi, merupakan jumlah terkecil dari analit yang dapat dideteksi menggunakan metode yang telah divalidasi. (g) batas kuantifikasi, level terendah sebuah analit dapat di kuantifikasi dengan derajat tertentu. (h) Robustness, kapasitas suatu metode untuk tidak terpengaruh oleh perubahan metodemetode kecil seperti $\mathrm{pH}$, laju alir, temperatur kolom, komposisi fase gerak yang dievaluasi pada rentang yang proporsional (i) Ruggedness, uji yang digunakan untuk mengetahui pengaruh perubahan kecil yang disengaja dalam parameter operasi dan kondisi lingkungan seperti laboratorium, analis, instrumen, hari yang berbeda, suhu dan bahan pereaksi (Ahuja \& Dong, 2005; Paithankar, 2013; Sibinovic, Smelcerovic, Palic, Dordevic, \& Marinkovic, 2005).

Pada industri farmasi terdapat tiga metode standar plot untuk kuantifikasi. Metode pertama, single-point calibration, merupakan metode pengembangan dan validasi yang menggunakan hanya satu konsentrasi standar. Metode ini lebih sederhana dan efisien tetapi memerlukan skema ekstraksi dan pengenceran yang berbeda pada berbagai variasi produk obat untuk memberikan konsentrasi final yang sama atau dekat degan konsentrasi analit satu standar. Kedua, multiple pointcalibrationmerupakan metode yang melibatkan dua atau lebih standar dimana rentang konsentrasi standar akan memberikan hubungan yang linier. Metode ini dapat dilakukan dengan menggunakan persiapan prosedur yang berbeda, namun kelemahannya beberapa penimbangan standar pada konsentrasi yang berbeda dapat memberikan kesalahan penimbangan. One standar calibration for each strength merupakan metode yang menggunakan satu konsentrasi standar untuk setiap produk. Hal ini muncul ketika analit tidak menunjukkan linieritas dalam kisaran konsentrasi yang wajar (Chan, Lee, Lam, \& Zhang, 2004).

\section{METODE PENELITIAN}

\section{Bahan}

Natrium seftriakson (Kemurnian 89,14\%) (Santacruz) sebagai working standard natrium seftriakson injeksi kemasan 1 gram (obat komersial), metanol (HPLC Grade, Merck), Air destilasi, TFA (Merck), natrium seftriakson hasil sintesis di laboratorium PTFM-BPPT. 


\section{Kondisi HPLC}

Fase gerak terdiri dari methanol dan air dengan TFA 0,1\%, laju alir $1 \mathrm{~mL} /$ menit. Fase diam yang digunakan adalah Kolom Inertsil ODS-3, C-18 (5 mm, 4,6 x $150 \mathrm{~mm}$,). Analisa dilakukan pada panang gelombang $235 \mathrm{~nm}$. Temperatur kolom $25^{\circ} \mathrm{C}$.

\section{Persiapan stok larutan standar}

Stok larutan standar sodium seftriakson $(1000 \mu \mathrm{g} / \mathrm{mL})$ dipersiapkan dengan pelarut air. Sebanyak $20,00 \mathrm{mg}( \pm 0.05 \mathrm{mg})$ natrium ceftriaxone standar ditimbang dan ditempakan ke dalam labu ukur $20 \mathrm{~mL}$. Air ditambahkan sebanyak $15 \mathrm{~mL}$, kemudian disonikasi hingga larut sempurna. Air ditambahkan hingga tanda batas . Dari larutan stok tersebut dibuat konsentrasi $200 \mu \mathrm{g} / \mathrm{mL}$ dengan menggunakan diluen fase gerak untuk uji kesesuaian sistem dan spesifitas/selektifitas

\section{Persiapan stok larutan kerja}

Natrium seftriakson (1000 $\mu \mathrm{g} / \mathrm{mL})$ dipersiapakan dengan menimbang sebanyak $20,00 \mathrm{mg}( \pm 0.05 \mathrm{mg})$ sodium seftriakson hasil sintesis ditimbang dan ditempakan ke dalam labu ukur $20 \mathrm{~mL}$. Air ditambahkan sebanyak $15 \mathrm{~mL}$, kemudian disonikasi hingga larut sempurna. Air ditambahkan hingga tanda batas. Larutan stok ini digunakan untuk membuat larutan kerja dengan menggunakan diluen fase gerak untuk uji linieritas $(0,12-500$ $\mu \mathrm{g} / \mathrm{mL}$ ), presisi $(100,140$, dan $200 \mu \mathrm{g} / \mathrm{mL}$ ), akurasi (100 dan $200 \mu \mathrm{g} / \mathrm{mL}$ ), robustness (200 $\mu \mathrm{g} / \mathrm{mL}$ ), limit of detection (LOD) dan limit of quantification (LOQ) $(0,12-500 \mu \mathrm{g} / \mathrm{mL})$

\section{Aplikasi}

Pengembangan dan validasi metode diaplikasikan untuk menentukan natrium seftriakson pada dua sediaan injeksi yang terdiri dari $1 \mathrm{~g}$ natrium seftriakson. Sediaan injeksi sefriakson yang setara dengan $1 \mathrm{~g}$ natrium seftriakson dilarutkan dengan air dan ditempatkan ke dalam labu ukur 1L. Air ditambahkan sebanyak $900 \mathrm{~mL}$ kemudian disonikasi selama 5 menit dan ditetapkan dengan air hingga tanda batas sehingga diperoleh konsentrasi $1000 \mu \mathrm{g} / \mathrm{mL}$. Dari larutan stok dibuat konsentrasi $200 \mu \mathrm{g} / \mathrm{mL}$ untuk memperkirakan kadar sediaan injeksi yang dibandingkan dengan standard secara point to point.

\section{HASIL DAN PEMBAHASAN}

Dari beberapa investigasi yang dilakukan diluar penelitian ini, telah diperoleh kolom dan fase gerak yang sesuai untuk analisa natrium seftriakson. Penggunaan kolom ODS-3, C-18 (5 mm, 4,6 x $150 \mathrm{~mm}$ ) dengan fase gerak yang terdiri dari methanol dan air 0,1\% TFA yang lebih ekonomis dan efisien dibandingkan dengan standar USP 42. Selain itu, pengguanaan fase grak tersebut menghasilkan kromatogram yang tajam dan simetrik . Absorpsi maksimum terjadi pada panjang gelombang $235 \mathrm{~nm}$ dimana panjang gelombang tersebut dipilih untuk analisa.

Metode validasi yang dilakukan pada penelitian ini yaitu kesesuaian sistem, spesifitas/selektifitas liniearitas, akurasi, presisi,robustness, batas deteksi dan batas kuantifikasi yang didasarkan pada pedoman $\mathrm{ICH}$ dan AOAC International.

\section{Kesesuaian sistem.}

Uji kesesuaian sistem pada penelitian ini dilakukan pada larutan standard seftriakson konsentrasi $(200 \mu \mathrm{g} / \mathrm{mL})$ pada kondisi fresh dengan diinjek ke dalam system HPLC $20 \mu \mathrm{L}$ sebanyak enam kali ulangan. Hasil uji menunjukkan waktu retensi diperoleh pada 4.12

Tabel 2. Uji Kesesuaian Sistem

\begin{tabular}{|l|l|l|}
\hline Parameter & Nilai & $\begin{array}{l}\text { Syarat } \\
\text { Keberterimaan } \\
\text { (Pedoman } \\
\text { AOAC) }\end{array}$ \\
\hline RSD & $0,31 \%$ & $\leq 3,0 \%$ \\
\hline Faktor tailing & 1,3 & $\leq 2,0$ \\
\hline $\begin{array}{l}\text { Plate count } \\
(N)\end{array}$ & 2305.167 & - \\
\hline
\end{tabular}

\section{Linieritas}

Linieritas di analisa dengan larutan kerja pada rentang $0,12-500 \mu \mathrm{g} / \mathrm{mL}$ dengan injeksi $20 \mu \mathrm{L}$ pada panjang gelombang $235 \mathrm{~nm}$. Kurva kalibrasi dibuat berdasarkan hubungan antara konsentasi dengan luas area (Gambar 1). Dari kurva kalibrasi diperoleh persamaan $\mathrm{y}=37669 \mathrm{x}$ 5198,9 dengan koefisien korelasi yang sangat baik yaitu $R^{2}=1$. 


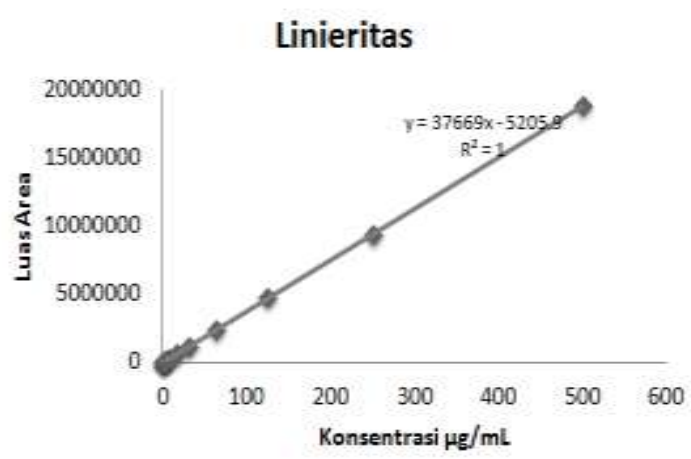

Gambar 1. Kurva standar seftriakson

\section{Spesifisitas}

Spesifisitas dievaluasi dengan membandingkan larutan standar dengan diluen (fase gerak) yang digunakan. Uji tersebut dilakukan menggunakan larutan standar konsentrasi $200 \mu \mathrm{g} / \mathrm{mL}$. , sedangkan diluen yang digunakan yaitu metanol : TFA 0,1 $\%$, 35:65 (v/v). Hasil kromatogram menunjukkan bahwa waktu retensi seftriakson pada 4-5 menit tidak terdapat gangguan dari peak pelarut terbukti dari nilai purity index 1 . Kromatogram diluen, standard dan peak purity index ditunjukkan pada Gambar 2.

\section{Presisi}

Uji presisi dilakukan pada tiga konsentrasi. Pada hari yang sama (intra day) dan hari yang berbeda (inter day) yang masing - masing dilakukan pada dua analis yang berbeda. Hasil uji presisi dapat dilihat pada Tabel 4.

\section{Akurasi}

Akurasi merupakan pendekatan antara nilai aktual dengan nilai kalkulasi. Uji akurasi dilakukan pada konsentrasi 100 dan $200 \mu \mathrm{g} /$ $\mathrm{mL}$ dengan pengulangan sebanyak tiga kali.
Pada penelitian ini uji akurasi ditentukan dengan metode single point calibration yaitu menggunakan hanya satu konsentrasi standar untuk plot kuantifikasi (Chan et al., 2004). Dari hasil uji untuk konsentrasi $100 \mu \mathrm{g} / \mathrm{mL}$ diperoleh nilai recovery $99 \%$, sedangkan untuk konsentrasi $200 \mu \mathrm{g} / \mathrm{mL}$ diperoleh nilai recovery 102\%. Tabel 3.

Tabel 3. Hasil Uji Akurasi.

\begin{tabular}{|c|c|c|c|}
\hline $\begin{array}{l}\text { Konsent } \\
\text { rasi } \\
\text { Sebena } \\
\text { rnya } \\
(\mu \mathrm{g} / \mathrm{mL}\end{array}$ & $\begin{array}{l}\text { Konsentrasi } \\
\text { Diperoleh } \\
(\mu \mathrm{g} / \mathrm{mL})\end{array}$ & RSD & $\begin{array}{c}\% \quad \% \\
\quad \text { Recovery }\end{array}$ \\
\hline 100 & 99 & 0,66 & 99 \\
\hline 200 & 205 & 1,3 & 102 \\
\hline
\end{tabular}

\section{Robustness}

Robustness dievaluasi dengan adanya variasi laju alir, komposisi fase gerak, temperature kolom. Laju alir divariasi dari 1 $\mu \mathrm{g} / \mathrm{mL}$ menjadi $0,8 \mu \mathrm{g} / \mathrm{mL}$ ). Komposisi fase gerak divariasi dari metanol - air TFA 0,1\%, (35:65, v/v) menjadi(30:70, v/v)Sedangkan kolom temperatur dari $25^{\circ} \mathrm{C}$ menjadi $40^{\circ} \mathrm{C}$. Dari perubahan kondisi sistem HPLC yang dilakukan dibandingkan dengan metode yangn digunakan untuk analisa dapat dilihat pada Tabel 5.

Waktu retensi untuk perubahan laju alir dan variasi komposisi fase gerak bergeser kearah kanan dimana tidak ada interferensi untuk pembacaan peak (indek purity 1), sedangkan untuk perubahan temperatur kolom waktu retensi bergeser kekiri dimana terjadi interferensi pembacaan peak dikarenakan peak bertumpuk dengan peak impurity yang dibuktikan dengan indek purity sebesar 0,9675 . 

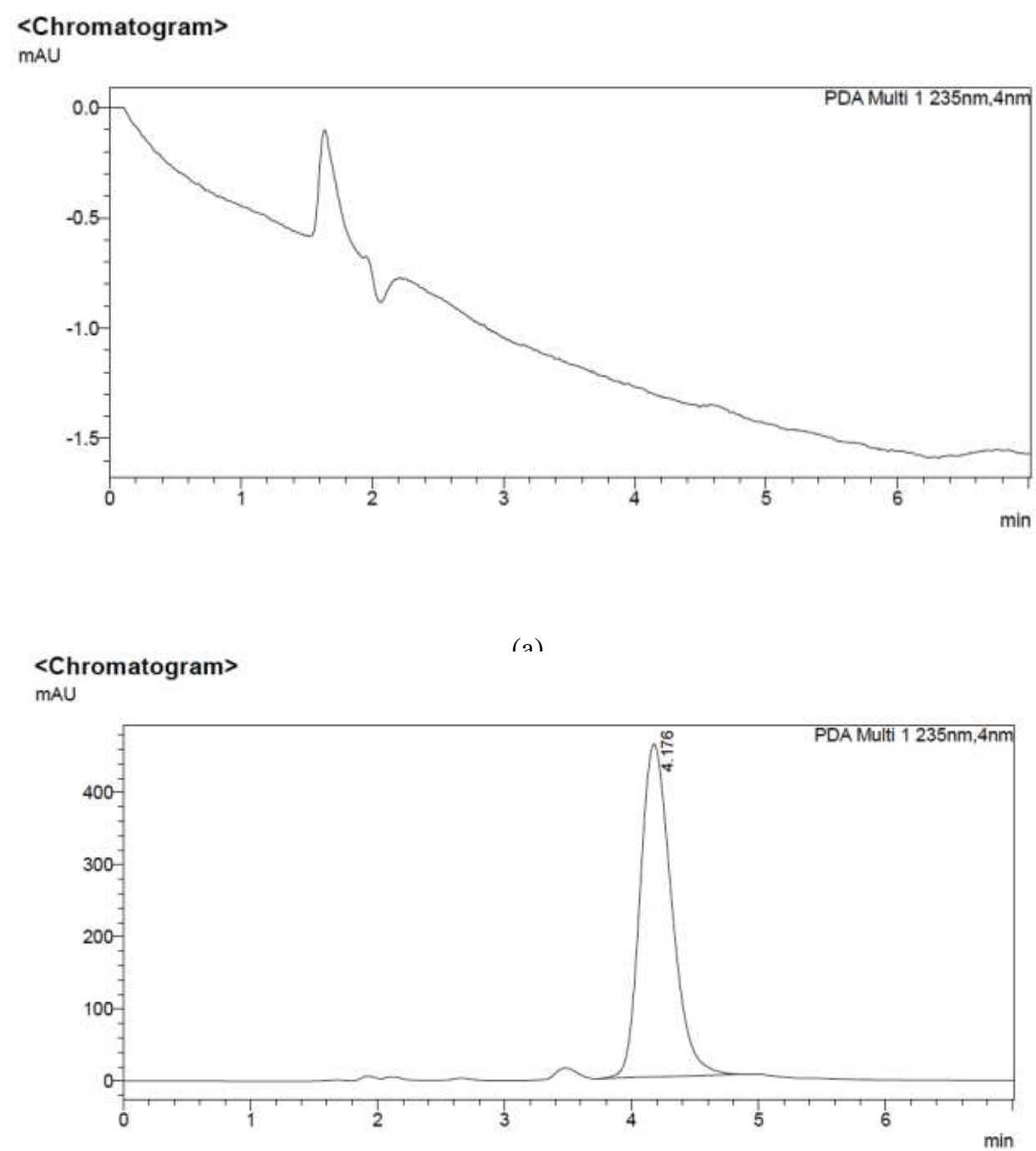

(b)

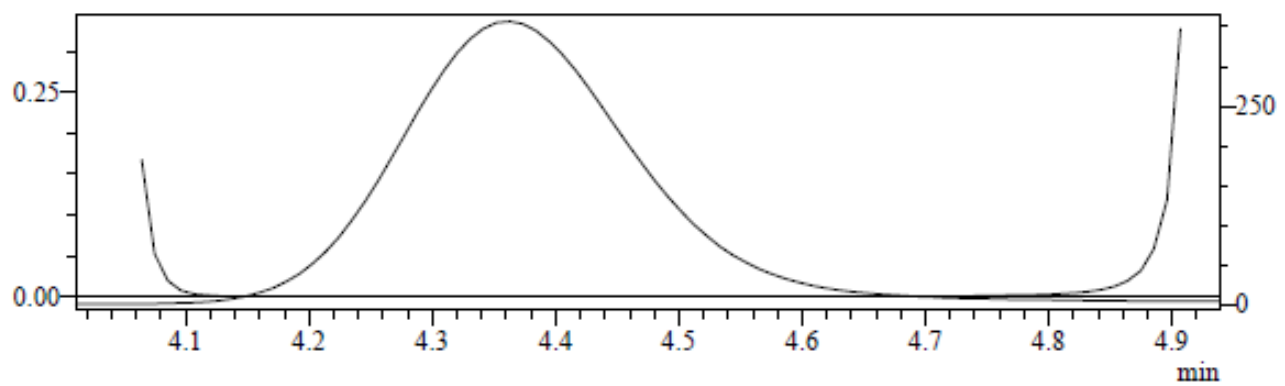

Impurity

Not Detected

Peak purity index $\quad: 1.000000$

Single point threshold $\quad: 0.999999$

Minimum peak purity index $\quad: 0$

(c)

Gambar 2. (a) Kromatogram diluen , (b) Kromatogram seftriakson , (c) Kromatogram purity

Tabel 4. Uji Presisi Natrium Seftriakson. 
Pengembangan Dan Validasi Metode High Performance Chromatography (Hplc) Untuk Analisis Sodium Seftriakson (Alfan Danny Ardianto, Maya Damayanti Rahayu, Susi Kusumaningrum, Rohimmahtunnisa Azhar, Raodatul Jannah)

\begin{tabular}{ccccc}
\hline Kons. & \multicolumn{2}{c}{ Intraday $(\boldsymbol{n}=3)$} & \multicolumn{2}{c}{ Inter day $(\boldsymbol{n}=3)$} \\
\cline { 2 - 5 }$(\boldsymbol{\mu} \mathbf{g} / \mathrm{mL})$ & Luas area \pm SD $(\boldsymbol{n}=3)$ & \%RSD & Luas area \pm SD $(\boldsymbol{n}=3)$ & $\% R S D$ \\
\hline 100 & $3946764+25887.21$ & 0.66 & $4211451+11229.28$ & 0.27 \\
140 & $5704786+20924.70$ & 0.37 & $6042622+57325.03$ & 0.95 \\
200 & $8176960+106256.26$ & 1.30 & $8151417+84584.66$ & 1.04 \\
\hline
\end{tabular}

Tabel 5. Uji Robustness.

\begin{tabular}{lllll}
\hline Variasi & $\begin{array}{l}\text { Waktu } \\
\text { retensi }\end{array}$ & \%RSD & Peak purity & Faktor Tailing \\
\hline Metode yang digunakan & 4,3 & 2,06 & 1 & \\
Variasi laju alir & 5,3 & 0,68 & 1 & 1,116 \\
Variasi komposisi fase gerak & 7,4 & 0,96 & 1 & 1,111 \\
Variasi temperatur kolom & 3,3 & 1,40 & 0,9675 & 0,910 \\
\hline
\end{tabular}

\section{Aplikasi}

Sediaan injeksi natrium seftriakson telah dianalisa menggunakan metode yang telah divalidasi. Dua sampel sediaan komersial yang mengandung $1 \mathrm{~g}$ natrium seftriaksondianalisadan menghasilkan data pada Tabel 6. Masing-masing sampel mempunyai indek purity 1 yang menunjukkan bahwa placebo tidak mempengaruh pembacaan peak, sehingga dapat dikatakan bahwa sampel sediaan terbaca 106,66 \% dan $118,00 \%$.

Tabel 6. Hasil Uji Sediaan Injeksi

\begin{tabular}{llcc}
\hline $\begin{array}{l}\text { Kode } \\
\text { Sampel }\end{array}$ & $\begin{array}{l}\text { Konsentrasi } \\
(\mu \mathrm{g} / \mathrm{mL})\end{array}$ & $\%$ Assay & $\begin{array}{l}\text { Purity } \\
\text { Index }\end{array}$ \\
\hline Sampel 1 & 200 & 106,66 & 1 \\
Sampel 2 & 200 & 118,00 & 1 \\
\hline
\end{tabular}

\section{KESIMPULAN}

Pengembangan dan validasi metode untuk analisa natrium seftriakson menggunakan fase gerak methanol-air 0,1 \%TFA (35:65) merupakan metode yang ekonomis, efisien, presisi dan dapat diaplikasikan untuk analisa rutin bahan baku natrium seftriakson dan produk sediaan.

\section{UCAPAN TERIMAKASIH}

Insinas Kemenristekdikti 2019

\section{DAFTAR PUSTAKA}

Ahuja, S., \& Dong, M. (2005). Handbook of pharmaceutical analysis by HPLC (Vol. 6): Elsevier.

Chan, C. C., Lee, Y., Lam, H., \& Zhang, X.-M. (2004). Analytical method validation and instrument performance verification: John Wiley \& Sons.

da Trindade, M. T., \& Salgado, H. R. N. (2018). A critical review of analytical methods for determination of ceftriaxone sodium. Critical reviews in analytical chemistry, 48(2), 95-101.

Danklmaier, J., Macher, I., \& Prager, B. (1996). Process for the synthesis of the disodium salt hemiheptahydrate of ceftriaxone: Google Patents.

Dolan, J. W., \& Snyder, L. R. (2017). Chapter 14 - Method development in liquid chromatography. In S. Fanali, P. R. Haddad, C. F. Poole \& M.-L. Riekkola (Eds.), Liquid Chromatography (Second Edition) (pp. 375-388): Elsevier.

Ethiraj, R., Thiruvengadam, E., Sampath, V. S., Vahid, A., \& Raj, J. (2014). Development and validation of stability indicating spectroscopic method for content analysis of Ceftriaxone sodium in Pharmaceuticals. International scholarly research notices, 2014.

Görög, S. (2005). The sacred cow: the questionable role of assay methods in characterising the quality of bulk pharmaceuticals. Journal of 
Pharmaceutical and Biomedical Analysis, 36(5), 931-937.

Hiremath, B., \& Mruthyunjayaswamy, B. (2009). Development and validation of a high-performance liquid chromatographic determination of ceftriaxone sodium and its application to drug quality control. Analytical Letters, 42(14), 2180-2191.

Paithankar, H. (2013). HPLC method validation for pharmaceuticals: a review. Int J Universal Pharm Bio Sci, 2(4), 229-240.

Shah, J., Jan, M. R., \& Shah, S. (2013). Development and validation of a spectrofluorimetric method for the quantification of ceftriaxone in pharmaceutical formulations and plasma. Luminescence, 28(4), 516522.

Shah, R., \& Jat, R. (2015). Develompent And Validation of Reversed Phase HPLC Method For Estimation Of Estimation
Of Ceftriaxone In Pharmaceutical Dosage Form. Journal of Drug Delivery and Therapeutics, 87-91.

Sibinovic, P., Smelcerovic, A., Palic, R., Dordevic, S., \& Marinkovic, V. (2005). Ruggedness testing of an HPLC method for the determination of ciprofloxacin. Journal of the Serbian Chemical Society, 70(7), 979-986.

Tariq, A., Siddiqui, M. R., Kumar, J., Reddy, D., Negi, P. S., Chaudhary, M., Singh, R. (2010). Development and validation of high performance liquid chromatographic method for the simultaneous determination of ceftriaxone and vancomycin in pharmaceutical formulations and biological samples. Science Asia, 36(4), 297-304. 